\title{
The Image of Ibrahim Pasha in Early Modern English Drama: Thomas Kyd's The Tragedy of Soliman and Perseda
}

\section{Erken Modern Dönem İngiliz Tiyatrosunda İbrahim Paşa İmgesi: Thomas Kyd'in Suleyman ve Perseda'nin Trajedisi}

\author{
Işıl Şahin GÜLTER*
}

\begin{abstract}
In The Tragedy of Soliman and Perseda, Thomas Kyd tends to portray Sultan Suleyman's reign in the context of sixteenth century Ottoman - European relations. In the aftermath of Sultan Suleyman's succession to the throne, Ottoman Empire expands its borders towards European territories conquering strategic holds such as Belgrade, Rhodes and Buda. Ottoman westward expansion increases cultural interaction between the Ottomans and the Europeans. More specifically, Ottoman presence in the Mediterranean stimulates Anglo-Ottoman relations. As a result of cultural interaction, the English playwrights frequently people their plays with Ottoman characters and historical episodes. Especially Sultan Suleyman, called 'Magnificent' in Europe, is widely depicted on the English stage. However, in this study, it is aimed to analyze Kyd's Erastus character constructed on the historical figure Ibrahim Pasha, since Ibrahim Pasha is regarded as one of the prominent figures of Sultan Suleyman's reign. Ibrahim, who is presented to the service of Suleyman in the years of his princely governorate in Manisa, becomes Suleyman's 'favorite' in a very short time. In the aftermath of Suleyman's succession to the throne in 1520, Ibrahim is conferred respectively honors of hasodabaşı, içşahincilerağası, grand vizier and beylerbeyi. Besides, Ibrahim is endowed with privileges that were never granted to the prior grand viziers. Nevertheless, at the peak of power and strength, he is summoned to the palace and executed. In Kyd's play, Erastus is also presented to the service of Suleyman as a war captive. They bound such an intimate relationship that Erastus is appointed to the highest ranks in the government and granted with many privileges. However, he is accused of treason and executed at the end of the play. Ultimately, this study aims to analyze the image of Ibrahim Pasha represented as Erastus character in Kyd's The Tragedy of Soliman and Perseda.
\end{abstract}

Key Words: Early modern English drama, Thomas Kyd, Grand vizier, Ibrahim Pasha, Sultan Suleyman.

Öz

Suleyman ve Perseda'nın Trajedisi'nde, Thomas Kyd on altıncı yüzyıl Osmanlı-Avrupa ilişkileri bağlamında Sultan Süleyman'ın saltanatını resmetmeyi amaçlar. Sultan Süleyman'ın tahta çıkmasının ardından, Osmanlı devleti Belgrad, Rodos ve Buda gibi önemli noktaları fethederek sınırlarını Avrupa'ya doğru genişletir. Osmanlı'nın Batıya doğru bu ilerleyişi Osmanlılar ve Avrupalılar arasındaki kültürel etkileşimi arttırır. Daha spesifik olarak, Osmanlı'nın Akdeniz'deki varlığı Osmanlı-İngiliz ilişkilerini de harekete geçirir. Kültürlerarası etkileşimin bir sonucu olarak, İngiliz oyun yazarları sıklıkla Osmanlı şahsiyetlerini ve tarihi olaylarını oyunlarına konu eder. Özellikle, Avrupa'da "Muhteşem" olarak bilinen Sultan Süleyman'a İngiliz sahnesinde genişçe yer verilir. Fakat, bu çalışmada, Kyd'in tarihi karakter İbrahim Paşa olarak resmettiği Erastus karakterinin incelenmesi amaçlanmaktadır, çünkü İbrahim Paşa, Sultan Süleyman saltanatının en öne çıkan isimlerinden biri olarak kabul edilir. Sultan Süleyman'ın Manisa'daki şehzadelik yıllarında hizmetine sunulan İbrahim, kısa sürede Şehzade Süleyman'ın en sevdiği adamı olur. Sultan Süleyman'ın 1520 yılında tahta çıkmasının ardından, sırasıyla hasodabaşı, içşahincilerağası, beylerbeyliği ve sadrazamlık mertebelerine yükseltilir. Bununla birlikte, daha önce hiçbir sadrazama tanınmamış ayrıcalıklarıyla dikkat çeker. Lakin ikbal ve gücün doruk noktasında iken, bir gece saraya çağrılarak idam edilir. Kyd'in oyununda, İbrahim Paşa olduğu kabul edilen Erastus karakteri de bir savaş esiri olarak Sultan Süleyman'a takdim edilir. Aralarında öyle kuvvetli bir bağ kurulur ki; Erastus da devletin en önemli mertebelerine yükseltilerek birçok ayrıcalıklara sahip olur. Fakat oyunun sonunda hainlikle suçlanarak idam edilir. Bu bağlamda, bu çalışma Thomas Kyd'in Süleyman ve Perseda'nın Trajedisi adlı oyununda, Erastus karakteri olarak resmedilen İbrahim Paşa imgesini incelemeyi amaçlar.

Anahtar Kelimeler: Erken modern dönem İngiliz tiyatrosu, Thomas Kyd, Sadrazam, İbrahim Paşa, Sultan Süleyman

\section{Introduction}

The forty-six yearlong reign of Sultan Suleyman (r. 1520-1566) holds a very special place in Ottoman history. Sultan Suleyman's reign is regarded as a golden age of the Ottoman Empire with expansion of the boundaries through constant conquests and the formulation of a

* Dr. Öğr. Gör. Fırat Üniversitesi, Yabancı Diller Yüksekokulu, igulter@ firat.edu.tr.

Gülter, I. Ş. (2019). The Image of Ibrahim Pasha in Early Modern English Drama: Thomas Kyd's The Tragedy of Soliman and Perseda, Gaziantep University Journal of Social Sciences, 18(1), 29-38, Submission Date: 14-072018, Acceptance Date: 22-01-2019.

Araştırma Makalesi. 
distinct Ottoman imperial identity. The campaigns and conquests towards central Europe and Mediterranean occupied the Sultan's main target. The Sultan's imperial ambition intensified Ottoman expansion towards Europe through conquests of strategic holds such as Belgrade, Rhodes, and Buda. Christian European states including Spain, France, Italy, and Germany were forced to accept Ottoman Empire as a military, commercial and diplomatic force. Even though English interest of Ottoman Empire developed nearly a hundred years after the establishment of relations between the Turks and the rest of Europe (Burian, 1952, p. 209), the cultural interaction between the Ottomans and the English began to flourish in the sixteenth century. As a result of this cultural interaction, the early modern English playwrights frequently peopled their plays with Ottoman characters. According to Louis Wann, forty seven plays staged Islamic themes and characters in the period between 1579 and 1642 and thirty one of these plays especially dealt with the Ottoman Turks and Ottoman history (Wann, 1915, p.439). For instance, Christopher Marlowe's Tamburlaine Part One and Part Two (1587-88), George Peele's Turkish Mahumet and Hiren the Fair Greek (1588) and The Battle of Alcazar (1589), Fulke Greville's Mustapha (1594), Robert Greene's Selimus (1594), Thomas Heywood's The Fair Maid of the West, or A Girl Worth Gold, Part I (1602) and Part II (1630), William Shakespeare's Othello (1604), Robert Daborne's A Christian Turned Turk (1610), and Philip Massinger's The Renegado (1624) clearly reflected English interest in Ottoman episodes and characters. Most of these plays employed plots about the Ottoman sultans, namely Murad I, Murad III, Bayezid I, Bayezid II, Mehmed II, Selim I, and Suleyman the Magnificent (Şenlen, 2006, p. 399). Representation of Ottoman sultans on early modern stage established an "archetypal sultan" image whose power "is bent on possession and domination" as Vitkus (2003) remarks as follows:

\begin{abstract}
A conventional set of characteristics for describing Islamic power had already been established: first, there is a sultan who exercises all the power, while all others merely obey. This sultan, in order to feed his passions, is bent on possession and domination. He desires to increase his physical boundaries of his realm and also to obtain women for his harem and capture souls for his religion... Because he has absolute power, he rules everyone but himself: his own passions are uncontrollable. This archetypal sultan is depicted as fickle and given to extreme, unstable desires, whims, and sudden fits of irrational anger. He perverts justice, enforcing Islamic law and all codes of honor to suit his whims and lusts (p. 115)
\end{abstract}

In dealing with Ottoman Sultans, the playwrights employed these conventional set of characteristics traditionally associated with the Turks. In the production of these dramatic representations, as Nabil Matar notes, "simplification and stereotyping were the rules by which [the English] represented Muslims” (1999, p. 14). Especially Daniel J. Vitkus's Three Turk Plays from Early Modern England: Selimus, Emperor of the Turks; a Christian Turned Turk; and the Renegado (2000) and Matthew Dimmock's New Turkes, Dramatizing Islam and the Ottomans in Early Modern England (2005) anlayzed all the aspects of the dramatic representations of the Turks in early modern period. However, this study aims to analyze the reconstruction of an episode of Ottoman history in the early modern English context. Through evaluating representation of Suleyman-Ibrahim story in Thomas Kyd's The Tragedy of Soliman and Perseda, this study tries to reach a deeper reading of the play than the present literature offers by focusing on one of the prominent figures of Sultan Suleyman's reign, Ibrahim Pasha. That is, although Kyd's play was partially analyzed and commented on representation of the Turk, this study will uniquely elaborate on reconstruction of Suleyman-Ibrahim story on early modern stage in the light of historical accounts. In this sense, my analysis of The Tragedy of Soliman and Perseda will focus on Kyd's reconstruction of the intimate relationship between Sultan Suleyman and Ibrahim Pasha, Ibrahim's swift promotion to the grand vizierate and his tragedy at the court of Sultan Suleyman with specific attention to the historical accounts. 


\section{Sultan Suleyman's Reign and Ibrahim Pasha's Career}

Sultan Suleyman, born in 1494, ascended to the throne in 1520, following his father Sultan Selim's death in Çorlu. The death of Sultan Selim was kept secret by the viziers Piri Pasha, Mustapha Pasha and Ferhad Pasha until his successor would replace him in order to prevent any uprising or plunder attempts among the janissaries (İnalc1k, 1973, p. 61). After Suleyman received the confirmation of his father's death, he rushed to Constantinople, and ascended to the throne in the imperial palace as the tenth sultan of the House of Osman (Yurdaydın, 1961, pp. 3-4). Sultan Suleyman ascended to the throne as a young ruler of a vast empire, in the age of the Habsburg Emperor Charles V, Martin Luther's Protestant movement, and the Safavi Shah Ismail in Iran (Kunt, Woodhead, 1995, p. 22). During Sultan Selim's reign, the main expansion in the empire occured in the east and the south. In 1514, at Çaldıran near Lake Van, Sultan Selim eliminated the urgent danger of Safavis defeating Shah Ismail's army. Then he marched his armies against the Mamluk sultanate of Syria and Egypt which resulted in the complete conquest of the Mamluk lands in 1516-1517. With these conquests, Sultan Selim announced himself as the defender of holy cities, Mecca and Medina, and therefore as the most important Sunni ruler in the Islamic world. Furthermore, Ottoman Empire became the strongest and the most prestigious power in the East (Gibb, 1962, pp. 287-295). The glorious and ambitious Sultan Selim turned his face to the West; Rhodes, Hungary, Sicily and Italy seemed to be his primary objectives in order to establish universal domination by uniting the East and the West. Sultan Selim's aspiration of universal domination uniting the East and the West caused distress among the European Christians that led them to unite for a crusade (Setton, 1976, pp. 170-180). However, Sultan Selim's death in 1520 caused a relief for the European Christians.

Nevertheless, a more powerful and glorious version of his father, Sultan Suleyman's reign awaited Western Europe. Sultan Suleyman's succession to the Ottoman throne terrified the rulers of Western Europe. At the court of King Henry VIII, Cardinal Wolsey said to the Venetian ambassador: "This Sultan Suleiman is twenty-five years old and has good judgment; it is to be feared he will act like his father" (Kinross, 1977, p. 197). Also in a letter to his ambassador, the Doge of Venice wrote: "The Sultan is young, very powerful and extremely hostile to the Christian race" (Kinross, 1977, p. 197). The campaigns and conquests towards central Europe and Mediterranean occupied Sultan's main targets. Sultan Suleyman conquered Belgrade in 1521 that was one of the major strongholds of Eastern Europe that led Christian power to fill with fear and anxiety for the upcoming victories. In 1523, Sultan Suleiman captured the Island of Rhodes and then in 1526 he defeated King Louis of Hungary at the Battle of Mohacs. Ottoman advance into central Europe, with possession of half of Hungary including Buda brought Turkish domination over most of southeastern Europe and increased Ottoman threat in Western Mediterranean. Sultan Suleiman marched to Vienna on May 10, 1529; however, the first Ottoman attempt to capture Vienna failed (Kunt, Woodhead, 1995, p. 24). Obviously, Sultan Suleyman's reign witnessed Ottoman expansion into central Europe with possession of many European territories. Sultan Suleyman's victories in the East and the West increased his self-confidence and experience that led him to make some changes within the state. In 1523, Suleyman did not want to rule any longer under the tutorship of grand vizier Piri Pasha against whom he felt himself constrained and couldn't enjoy his own sultanate (Peçevi, 1980, p. 20). In other words, Suleyman aimed to curb the influence of his father's experienced but manipulative statesmen over his reign. In this regard, Suleyman's reign and his political maturity aligned with the rise of Ibrahim Pasha who guaranteed Suleyman's favor and affection through his intelligence and skills in the Empire.

Ibrahim Pasha, Sultan Suleyman's 'favorite' is regarded as the most magnificent and powerful of all Ottoman grand viziers; he is the Sultan's alter-ego (Necipoğlu, 1989, p. 405). 
From his appointment to the grand vizierate in 1523 until his execution in 1536 on the order of Sultan, Ibrahim Pasha exerts a decisive influence and power equal to the Sultan's own in Ottoman Empire. Ibrahim Pasha's origin is investigated by historian Tayyib Gökbilgin as he details in his article "İbrahim Paşa" in Islam Ansiklopedisi. Gökbilgin cites important European accounts on Ibrahim Pasha including Venetian ambassador Pietro Zen's report, Thomas Artus's $L$ 'Histoire de la decadence de l' empire grec et establissment de celuy des turcs, French translation of Giovanni Sagredo's seventeenth century Italian history, and Austrian historian Joseph von. Hammer's early nineteenth century history of Ottoman Empire. More importantly, the famous sixteenth-century Italian historian Paolo Giovio's Histories is regarded as the main source of reference for these later European accounts (Turan, 2007, p. 130). In his section allocated to the famous Ibrahim Pasha, Giovio remarks Ibrahim's origin as follows:

\begin{abstract}
Born in a hamlet above Parga in the country of Butintro in Albania, he was taken away according to the custom of the Turkish rulers, who collect Christian boys. In his early youth he served Iskender Pasha...In this Iskender Pasha's place, Ibrahim, having accepted the Muhammadan religion, with marvelous skills, since he was quick witted, learned to read Arabic, write, and to play the lyre very well... Since he was pleasant in every action, a gentile speaker, and always courteous, he delighted this man of severe war and fighting. For that reason he was sent as a gift to Suleyman, the son of Sultan Selim, as a slave of great manners, while the grandfather Bayezid was still alive. Also he [Suleiman] cherished the most pleasant and gentile manners of this sharp boy to such an extent that he was raised with Suleyman at the same time and in all accounts of elegance he satisfied well the liking of the master (Turan, 2007, p. 131).
\end{abstract}

Similar to Giovio's account of Ibrahim Pasha, Gökbilgin cites that Ibrahim Pasha was born in Parga, recruited by Ottoman forces during a campaign, and presented to the service of Suleyman when he was in Manisa. Also known as "Pargal1," "Frenk," and "Maktul", Ibrahim was able to maintain his intimate relationship with Suleyman since the days of Suleyman's princely governorate (Gökbilgin, 1949, p. 908). In a short time, Ibrahim became Suleyman's 'favorite' and accompanied him from Manisa to Istanbul when he succeeded his father in 1520 . Following Suleyman's succession to the throne, Ibrahim was appointed as hasodabaşl which means the head of the privy chamber or the royal bedroom who was in constant contact with the Sultan, guarded him even in his sleep and accompanied him everywhere (İnalc1k, 1973, p. 80). In 1523, following Suleyman's return from Rhodes, Ibrahim was appointed as the grand vizier at the head of government, administration and army. Ibrahim's appointment to the grand vizirate was attributed not only to Suleyman's affection to him, but also to his skills and talents as well as Suleyman's discomfort with his grand viziers Piri Pasha and Ahmed Pasha as stated above. With Ibrahim's appointment to the grand vizierate, Suleyman granted him also the privilege to hold the divan (council) meetings in his own palace built for him at the Hippodrome of Istanbul; a novelty which became the norm for the later grand viziers (İnalc1k, 1973, p. 95). Following his appointment, he was conferred another honor, beylerbeyi of Rumelia. The appointment of Ibrahim to the grand vizierate was regarded as a violation of the promotion of state officials. According to Koçi Bey, Sultan Suleyman violated the rules of state officials' promotion by appointing Ibrahim so quickly to the grand vizierate. Koçi Bey criticized Ibrahim's appointment on the grounds of his inexperience in the fields of military and administrative training and attributed his appointment to the beginning of the Ottoman decline (Turan, 2007, p. 182). It is obvious that Ibrahim's quick rise to power not because of his experience in state affairs but solely because of Sultan's favor was not just an unusual situation in Ottoman political life, but also a disregard for the elite's ideals and expectations. However, Ibrahim's rise to the grand vizierate was also narrated as source of celebration upon Piri Pasha's resignation from his office by his own will. Peçevi (1980) remarks this phenomenon as follows:

The sultan's affection for [İbrahim] had increased to the point that it was even rumored that he wanted to make him grand vezir. This rumor had reached the ear of [Piri] Mehmed Pasha. One day the sultan said to Mehmed Pasha, "I want to promote to the outer service a slave for whose service I am infinitely grateful, but I just don't know what office I should appoint him to." When [the sultan] asked this of 
Mehmed Pasha, the latter answered, "It is my office that should be given to such a close and esteemed slave." And so the sultan made İbrahim, who was head [page] of the privy chamber, grand vezir, and promoted him to the outer service (p. 20).

According to Peçevi, Piri Pasha resigned from his office by his own will and Ibrahim was appointed to the grand vizierate following his resignation. However, the second vizier Ahmed Pasha, who was sent away from the center to govern Egypt rebelled and proclaimed his independence in Egypt. Ahmed Pasha's rebellion was suppressed successfully by Ibrahim Pasha who was conferred another honor beylerbeyi of Egypt. Ibrahim's success in Egypt was followed by his military competence at the battle of Mohac and his administrative competence in suppressing the uprisings in Anatolia following Hungarian campaign that increased his fame and self-confidence (Emecen, 2000, p. 334). Especially the Hungarian campaign had far broader consequences for the rest of Ibrahim's political career who began to have great power over the government. In this regard, his monopoly in the diplomatic negotiations proved his enormous power and influence equal to a sultanic power and authority beyond any other vizier had ever held over the Empire. During the Persian campaign against Safevis, Ibrahim announced that he was taking the title of serasker sultan and marched to Baghdad. During this campaign, Ibrahim fell into disagreement with defterdar Iskender Çelebi that resulted in Çelebi's execution in the marketplace in Baghdad. This total monopoly and imitative sultanic power caused Suleyman's dissatisfaction with Ibrahim Pasha (Emecen, 2000, p. 334). In 1536, Ibrahim was called to the palace for iftar, and he was strangled by the mutes. Andre Clot (2012) remarks on his death as follows:

What an extraordinary and romantic career! A son of a fisherman still under 30 years of age when he attained the highest positions in the most powerful empire of his time, husband of the sultan's sister and almost his equal - only to be cut down one night, at the height of his prestige, caught in the trap laid by the mute servants of the Seraglio! ( part 1, para.77).

It can be inferred that Ibrahim's swift promotion to the highest position in the Ottoman Empire resulted in his tragedy although history has preserved no record of the fact. Although there was much speculation about what could have led Suleyman to command his execution, everything indicated that his recent errors and attitudes exerted a decisive influence. It was alleged that his ambition for the sultanate, his disapproved behaviors following Iraq campaign, and the intrigues of Hurrem Sultan caused his downfall (Emecen, 2000, p. 334).

\section{The Image of Ibrahim Pasha in Thomas Kyd's The Tragedy of Soliman and Perseda (1588)}

The forty-six yearlong reign of Sultan Suleyman (1520-1566) holds a very special place in Ottoman history. Sultan Suleyman's age is regarded as a golden age since the Empire recorded numerous military and political victories during his reign. Sultan Suleyman's expansionist policy was compared to the imperial quest of Alexander the Great. Lord Kinross (1977) remarks this phenomenon as follows:

Immersing himself in the story of Alexander the Great, it became Suleiman's ambition to unite, as Iskander had sought to do, the lands and peoples of East and West. In pursuit of a comparable world empire, he would penetrate far beyond the present Ottoman fringe of Eastern Europe, right into the heart of central Europe itself (p. 175).

Suleyman's westward expansion was regarded as an imperial ambition to unite the lands and peoples of the East and the West. Especially during Sultan Suleyman's reign, the Ottoman presence in the Mediterranean brought about cultural interaction between the Ottomans and the English. As a result of this interaction, English playwrights produced a group of plays that deal with Sultan Suleyman's reign. Sultan Suleyman first appeared in an anonymous Cambridge play Solymannidea Tragedia (1581). Following this play, Sultan Suleyman appears in Thomas Kyd's The Tragedy of Soliman and Perseda (1588), Fulke Greville's The Tragedy of Mustapha (1594), Roger Boyle's The Tragedy of Mustapha, the Son of Solyman the Magnificent (1668), 
and Elkanah Settle's Ibrahim the Illustrious Bassa (1676). The English audience was also familiar with Ibrahim Pasha and his intimate relationship with Sultan Suleyman through these plays.

In the Tragedy of Soliman and Perseda, Ibrahim as Erastus is referred as Suleyman's "other best beloved" as recorded in the historical accounts. The story of Ibrahim was told in a sixteenth century prose tale in Jacques Yver's Le printemps d'Yever, contenant cinq histoires discourues par cinq journees, en une noble compagnie, au choteau du printemps (1572). Kyd's tragedy is based on Henry Wotton's translation of Le printemps as A Courtlie Controversie of Cupid's Tales (1578) (Akalın, 2001, p. 151). Kyd follows Wotton's Erastus-Perseda-Suleyman plot constructing Erastus on the historical figure Ibrahim drawing upon Ibrahim's depiction in the historical accounts. In The Tragedy of Soliman and Perseda, Erastus, Perseda's lover, is a Rhodian knight who flees to Constantinople. He is captivated by the Turks and presented to the service of Sultan Suleyman. Meanwhile, Perseda decides to follow Erastus on his way to Constantinople; however she is also taken as prisoner and presented to Sultan Suleyman. Suleyman falls in love with Perseda, nevertheless he permits reunion of the lovers and allows them to leave for Rhodes. Suleyman, counseled by Brusor, is convinced to get rid of Erastus in order to retrieve Perseda. Erastus is called back by Suleyman and he is accused of treachery and beheaded. In order to avenge Erastus's death, Perseda disguises herself as a man and resists against Turks' advance into Rhodes. However, as the Turks advance to the walls of Europe, Perseda falls, but before dying, she kills Suleyman by kissing him with poisoned lips. Although this play departs markedly from historical line, there are strong references to the intimate relationship between Sultan Suleyman and Ibrahim Pasha. In the course of the play, Kyd emphasizes not only Ibrahim's special treatment by the Sultan but also his tragedy at the court of the Suleyman.

The curtain is raised and Ottoman siege of Rhodes is displayed. In the first act Sultan Suleyman enters and announces his ambition of Rhodes's conquest:

For by the holy Al-Koran I swear

I'll call my soldiers home from Persia,

And let the Sophie breath, and from the Russian broils

Call home my hardy, dauntless Janissaries, ...

And from the other skirts of Christendom

Call home my Bassows and my men of war,

And so beleaguer Rhodes by sea and land.

That key will serve to open all the gates

Through which our passage cannot find a stop

Till it have pricked the heart of Christendom,

Which now that paltry island keeps from scath (The Tragedy of Soliman and Perseda, I.v.7-17).

It can be inferred that as an early modern playwright Kyd draws the attention to the importance of Rhodes defined as a "key" to "the heart of Christendom" and rapid Ottoman expansion into Europe. In the play, during the siege of Rhodes many Christians are brought as captives to Constantinople including Erastus and Perseda. Erastus is presented to Sultan Suleyman by his counsel Brusor: "This is Erastus, the Rhodian worthy,/ The flower of chivalry and courtesy" ( TOSP III.i.67-68). Evidently, this play departs markedly from historical line 
since Ibrahim is presented to the service of Suleyman in the days of his princely governorate in Manisa. In other words, Kyd reproduces the Ottoman conquest of Rhodes and Ibrahim's presentation to the service of Sultan Suleyman on early modern stage departing from historical line. Upon presentation of captive Erastus, Sultan Suleyman assures him of Ottoman justice in contrast to preconceived Christian European notions of the Turks:

What misery? Speak; for, though you Christians

Account our Turkish race but barbarous,

Yet have we ears to hear a just complaint...

And justice to defend the innocent,

And pity to such as are in poverty,

And liberal hands to such as merit bounty (TOSP III.i.58-63).

It can be inferred that Kyd refers to Sultan Suleyman's justice for all his subjects disregarding their nation or religion. In this respect, Suleyman's reign is regarded as a golden age precisely because his reign provided prosperity through protection and justice with systematic regulation of criminal, administrative and constitutional laws that had been validated during the reigns of prior sultans. The Sultan's kanun assured justice for all his subjects that accorded him with the highest respect - Kanuni, the law-abiding, the law-giver (Kunt, Woodhead, 1996, p. 28). Within the domains of the House of Osman, imperial justice reigned over all the subjects. In the play, captive Erastus and Sultan Suleyman enjoy such an intimate relationship that he is granted with the liberty to live as a Christian and Suleyman's intimate friendship:

Aye, that, or anything thou shalt desire;

Thou shalt be Captain of our Janissaries,

And in our Council shalt thou sit with us,

And be great Soliman's adopted friend... (TOSP III.i.97-100).

Kyd's reference to Erastus's Christianity and his demand of religious liberty draws attention to the discussions about Ibrahim's religious origin. During his grand vizierate Ibrahim is known for his interest in statues. He is widely criticized because of the idols in his palace's garden, and he is accused of idolatry (Emecen, 2000, p. 334). In his travel accounts of Istanbul, Dernschwam (1987) states that Ibrahim never changed his religion and lived as a Christian disguising himself (pp. 139-140). In other words, Ibrahim's religious origin has been a point of discussion during his grand vizierate and Kyd refers to Ibrahim Pasha's religious origin on early modern stage.

Erastus, Suleyman's "adopted friend", is appointed to the head of government, administration and army. Kyd refers to the intimate friendship between Suleyman and Ibrahim and Ibrahim's appointment to the grand vizierate in 1523 following Suleyman's return from Rhodes. Although Kyd's sequence of events is anachronic, he draws attention to Ibrahim's appointment to the grand vizierate. As the head of government, administration and army, he is granted with the privilege to hold divan (council) in his own palace built at the Hippodrome of Istanbul. Kyd refers to Ibrahim's accompanying the Sultan everywhere even during his private leisure time. In the third act, Suleyman offers Erastus to accompany him as follows:

And now, Erastus, come and follow me,

Where thou shalt see what pleasures and what sports ... 
My minions and my eunuchs can devise,

To drive away this melancholy mood. (TOSP III.i.149-152).

It is clear that Kyd refers to Ibrahim's appointment as the chief falconer, içşahinciler ăgası. As Emecen (2000) argues in his article, Sultan Suleyman was so charmed by Ibrahim's performance and wit that he took him as his inseparable companion, and appointed him the chief falconer (p. 333). The title indicates that Ibrahim would accompany Suleyman while hunting, which was the principle activity Suleyman would enjoy during his private leisure activity. In the course of the play, Kyd refers to Suleyman's special treatment of Ibrahim, as Erastus specifies that he is constantly granted with "rich embroidery, or costly ornaments,/ honors titles, wealth or gain" (TOSP IV.i.15-16). Not only had Ibrahim been raised to the position of hasodabaşı, içşahincilerăgası, grand vizier and beylerbeyi as a capable person and a close companion to Suleyman, but he was also granted with privileges that prior viziers never experienced. Mansel (1995) draws attention to Suleyman's special treatment of Ibrahim as follows:

Costume was governed by dynastic priorities. Whereas his predecessors had worn camelot or mohair, Suleyman wore cloth of gold. Although in theory it was reserved for the sultan alone, as a special favour he permitted his beloved Grand Vizier, Ibrahim Pasha, to Wear 'gold brocade and on campaign a suit of cloth of gold' (p. 66).

It can be inferred that the Sultan wore cloth of gold that was specific to his magnificence; however Ibrahim was also allowed to wear gold costumes. In the Ottoman Empire, the ideal of magnificence as an indispensable attribute of sovereignty was closely related with display of gorgeous ornaments in gold, diamond, emeralds, rubies and pearls during Ibrahim's grand vizierate. According to Necipoğlu (1989), Ibrahim encouraged the sultan to indulge himself in jewels as an ideal of magnificence. Ibrahim, Sultan's 'favorite' and partner in government, was recorded as a skilled architect of the Sultan's universal image due to his interest in the history of ancient kings, including Hannibal and Alexander the Great as well as the circumstances of present monarchs of the world (p. 405). During his grand vizierate, Ibrahim designed display of the Ottoman wealth, power and legitimate sovereignty to the European audience. An enormous fortune was spent to exhibit the sultan's magnificence to the world "in the manner of ancient Roman triumphs" (Necipoğlu, 1989, p. 407). According to a Venetian report, the Sultan's various triumphal parades including spectacular entry into Belgrade stupefied the Habsburg ambassadors due to the abundance of jewels and gold, and turned into "speechless corpses" (Necipoğlu, 1989, p. 409). That is, through his interest in the history of ancient kings and the circumstances of present monarchs of the world, Ibrahim Pasha holds a special place in constructing Sultan Suleyman's image and displaying his magnificence to the world.

In the play, Suleyman and Erastus develop a special friendship as Suleyman announces that they "are friends but one mind in two bodies" and assures Ibrahim that his friendship's "constancy" would never end (TOSP IV.i.29-30). According to Baudier, a $17^{\text {th }}$ century chronicler, Suleyman promised Ibrahim that as long as he reigned, whatever the circumstances, Ibrahim would never be put to death. Bauider adds that however "the condition of kings, like that of other people, is constantly changing; and favourites are often proud and ungrateful. This was what led Suleiman to forget his promise and Ibrahim to fail in loyalty and duty" (Clot, 2012, part 1, para. 81). In the course of the play, Perseda's presentation to the Sultan changes the dynamics between Suleyman and Ibrahim, since Suleyman falls in love with Perseda: "A sweeter creature nature never made;/ Love never tainted Soliman till now./ Now, fair virgin, let me hear thee speak" (TOSP IV.i.88-90). However, Perseda loves Erastus and rejects Suleyman's love. Upon this rejection, Suleyman allows them to reunite and leave for Rhodes:

Go, Janissaries, call in your Governor, 
So shall I joy between two captive friends,

And yet myself be captive to them both

If friendship's yoke were not at liberty; --

See where he comes, my other best-beloved (TOSP IV.i.151-155).

Suleyman allows them to reunite; however devoured by passion and longing for Perseda, he regrets allowing them to leave for Rhodes. Upon Suleyman's regret, Brusor counsels that:

This shall be the means; I'll fetch him back again,

Under color of great consequence;

No sooner shall he land upon our shore,

But witness shall be ready to accuse him

Of treason done against your mightiness,

And then he shall be doomed by marshal law (TOSP IV.i.244-249).

Brusor counsels Erastus's death for Suleyman's reunion with Perseda. He decides to accuse him of treason against Suleyman. He is brought to Suleyman's court and strangled by the mutes. Although in Ottoman and European accounts there was no clear reason that led Suleyman to command his execution, Kyd refers to Ibrahim's tragedy at the court of Suleyman for the sake of a Christian virgin. In order to avenge Erastus's death, Perseda disguises herself as a man and fights against Suleyman whom she kills by kissing with poisoned lips.

\section{Conclusion}

This study aims to show how an early modern playwright Thomas Kyd constructs his fictional character Erastus on the historical figure Ibrahim Pasha in his The Tragedy of Soliman and Perseda. Although there are some digressions from the historical context, Kyd's play is based on the intimate relationship between Sultan Suleyman and Ibrahim Pasha, whose tragedy at the court of Sultan Suleyman occured following his rise to the grand vizieate. Apparently, Kyd's play draws upon historical accounts that deal with Sultan Suleyman's reign and Ibrahim Pasha's decisive influence over his reign. It is obvious that Ibrahim Pasha, Sultan Suleyman's 'favorite', experiences special treatment and many privileges in the empire. Irrespective of his national and religious difference, Ibrahim embodies the Sultan's justice over all of his subjects. Furthermore, Ibrahim Pasha, the Sultan's "alter ego," embodies his public image in the Empire that extends his sultanic power and control over his subjects asserting his public visibility. Meanwhile, Ibrahim Pasha exerts a decisive influence on the representation of the Sultan's magnificence to the European audience. In other words, Sultan's 'favorite' also constructs a magnificent world ruler image for the Sultan utilizing his interest in the history of ancient kings as well as the circumstances of present monarchs of the world. Drawing upon previous discourses about Ibrahim Pasha, Kyd constructs his character Erastus on Ibrahim Pasha and displays him on early modern stage. Kyd emphasizes Sultan Suleyman's special treatment of Ibrahim Pasha and the intimate relationship between the two. He displays Ibrahim's swift promotion in the Empire and his tragedy at the court of Sultan Suleyman. Although Kyd displays Ibrahim's tragedy as a result of Suleyman's love for Perseda, history has preserved no record of the fact for Ibrahim Pasha's tragedy at the court of Sultan Suleyman. To sum up, in Kyd's The Tragedy of Soliman and Perseda, Erastus character is constructed on the historical figure Ibrahim Pasha and depicted as Sultan Suleyman's 'favorite' drawing upon historical accounts that deal with Sultan Suleyman's reign and Ibrahim Pasha's influence over his reign. 


\section{References}

Akalın, Esin. (2001). Discovering self and other: representation of Ottoman Turks in English drama. Unpublished Ph.D Thesis. University of Toronto, Toronto.

Burian, Orhan. (1952). Interest of the English in Turkey as reflected in English literature of the Renaissance. Oriens Vol.5. No. 2 p. 209- 229.

Clot, Andre. (2012). Suleiman the Magnificent. [Epub Version] London: Saqi books.

Dernschwam, Hans. (1987). İstanbul ve Anadolu'ya seyahat günlüğü, Çev. Y. Önen. Ankara: Kültür bakanlığı yayınları.

Emecen, Feridun. (2000). İbrahim Paşa, Makbul. Türk Diyanet Vakfi İslam Ansiklopedisi. Cilt: 21. İstanbul. p.333-335. http://www.islamansiklopedisi.info/dia/pdf/c21/c210260.pdf, A.D. 05.07.2018.

Gibb, Hamilton AR. (1962). Luṭī Paşa on the Ottoman Caliphate. Oriens. 15 p. 287-295.

Gökbilgin, Tayyib. (1949). İbrâhîm Paşa, Pargal1, Frenk, Makbûl, Maktûl. İslâm Ansiklopedisi. p. 908-915.

İnalc1k, Halil. (1973). The Ottoman Empire: the classical age 1300-1600. Trans. C. Imber and N. Itzkowitz. New York: Praeger publishers.

Kinross, Lord. (1977). The Ottoman centuries: the rise and fall of the Turkish Empire. New York: Morrow.

Kunt, Metin,\& Woodhead, Christine. (1995). Suleyman the Magnificent and his age: the Ottoman Empire in the early modern world. New York: Longman publishing.

Kyd, Thomas. (2002). The tragedy of Soliman and Perseda. Transcribed by BF. http://www.elizabethanauthors.org/soli102.htm, A.D. 01.06.2018.

Mansel, Philip. (1995). Constantinople: city of the world's desire (1453-1924). London: Penguin books.

Matar, Nabil. (1999). Turks, Moors, and Englishmen in the age of discovery. New York: Columbia University press.

Necipoglu, Gülru. (1989). Suleyman the Magnificent and the representation of power in a context of Ottoman-Habsburg-Papal rivalry. Art Bulletin 71 p. 401-27.

Peçevi, İbrahim. (1980). Tarih-i Peçevi. İstanbul: Enderun kitabevi.

Setton, Kenneth Meyer. (1976). The Papacy and the Levant, 1204-1571. Vol. 4. Philadelphia: American philosophical society.

Şenlen, Sıla. (2006). Ottoman sultans in English drama between 1580-1660. AÜ Osmanlı Tarihi Araştırma ve Uygulama Merkezi Dergisi 19 p. 399-405.

Turan, Ebru. (2007). The Sultan's favorite: Ibrahim Pasha and the making of the Ottoman universal sovereignty in the reign of Sultan Suleyman (1516-1526). Unpublished Ph.D Thesis. The University of Chicago, Chicago.

Vitkus, Daniel J. (2003). Turning Turk: English theater and the multicultural Mediterranean, 1570-1630. New York: Palgrave Macmillan.

Wann, Louis. (1915). The Orient in Elizabethan drama. Modern Philology 12, No. 7 p. 423447.

Yurdaydın, Hüseyin G. (1961). Kanuni'nin cülusu ve ilk seferleri. Ankara: Türk tarih kurumu basımevi. 